\title{
SMALL TOWNS AND RURAL AREAS - AS A PROSPECTIVE PLACE OF MODERN RETAIL TRADE FORMATS IN POLAND
}

Małgorzata Twardzik ${ }^{1}$, Krystian Heffner ${ }^{2}$

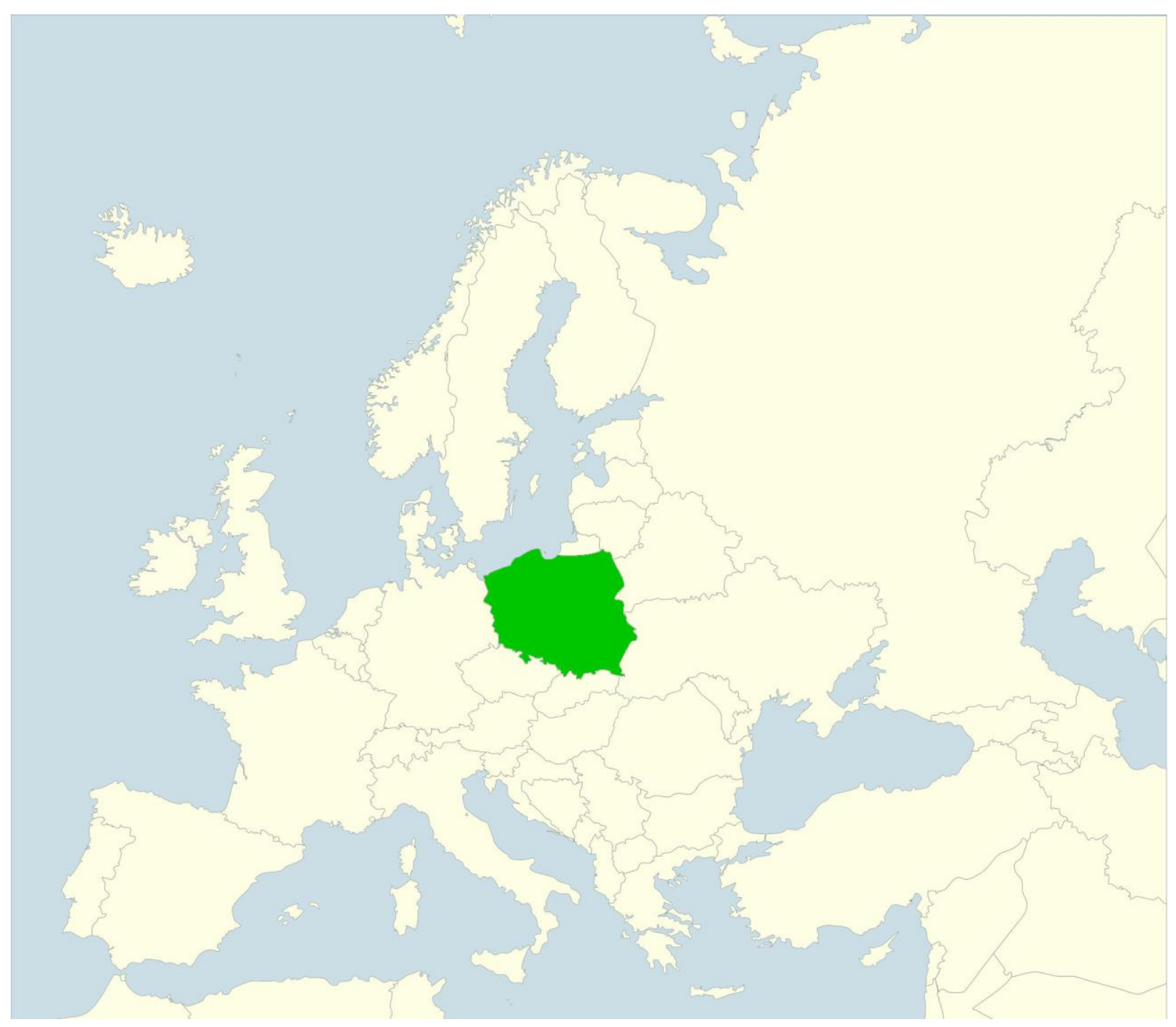

${ }^{1}$ Dr. Inż Małgorzata Twardzik, University of Economics in Katowice, Poland, malgorzata.twardzik@ue.katowice.pl. ORCID: 0000-0002- 1073-0176

2 Prof. zw. hab dr. Krystian Heffner, Silesian University in Opava, Czechia, heffner@ue.katowice.pl. ORCID: 0000-0002-2737-6417 
Abstract: Retail trade and services are becoming the most dynamically developing sector of non-agricultural activity in Polish rural areas. State-owned and cooperative stores have been closed down and they were replaced mostly by private stores. There are more and more commercial outlets of various formats, including supermarket chains, discount stores and integrated chains. Despite growing number of modern retail trade formats, traditional small-format, often referred to as local market is also really important. New trading posts in small towns and rural areas are mainly located in the zones of influence of larger cities. They affect many changes of spatial, social and economic character. Small towns and rural areas surrounding them more and more frequently start to compete for further retail trade investments while noticing lots of benefits and costs of this process. The aim of the article is to show the scale of new retail investment in small towns and rural areas in Poland. Research devoted to this field is important from the point of view of choosing the location of new investments related to discount chains and of the strategy for the development of small towns and rural areas. Identification of consequences of the operation of discount chains in chosen rural areas and in small towns can impact the verification of the policy adopted by local authorities in relation to spatial planning and forming the functional structure.

Key words: retail trade, retail trade formats, small towns, rural areas in Poland, discount stores, rural development

Streszczenie: Handel detaliczny ulega w Polsce nieustającym zmianom strukturalnym, ilościowym oraz jakościowym. Powstają nowe formaty handlu wielkopowierzchniowego, systematycznie maleje liczba sklepów, głównie małych, tradycyjnych placówek. Powstają w ich miejsce sklepy dyskontowe, stosujące strategię niskich cen, supermarkety, sieci zintegrowane detalistów oraz wielofunkcyjne galerie handlowe. Małe miasta i obszary wiejskie w Polsce dysponujące dotychczas ofertą tradycyjnego handlu - stały się dla inwestorów sieci detalicznych intratnym miejscem lokowania swoich działalności. W wyniku ich ekspansji w małych miastach oraz w obszarach wiejskich w otoczeniu dużych miast powstają supermarkety, sklepy dyskontowe i sieci zintegrowane największych operatorów handlowych w Europie. Mieszkańcy korzystają z ich oferty a lokalni przedsiębiorcy zmagają się $z$ rosnącą konkurencją. Zmienia się też zagospodarowanie przestrzenne miast, gdyż sieci mają określone wymagania lokalizacyjne, dostępnościowe oraz techniczne ( np. typ budynku, wielkość działki). Obszary wiejskie, dotychczas pomijane w drodze ekspansji sieci handlowych - staja się coraz częściej miejscem lokalizacji nowych form sieciowego handlu detalicznego.

Słowa kluczowe: handel detaliczny, formaty handlu, sieci dyskontowe, małe miasta, obszary wiejskie w Polsce, rozwój obszarów wiejskich

\section{Introduction}

As a result of economic, among others, changes affecting Poland since the beginning of 1990s agriculture sector has become an increasingly less profitable form of business activity. Managing observed surplus in labour force in rural areas that could contribute to economic activation of rural areas became obvious. The necessity to diversify their economic structure through development of all forms of entrepreneurship in creation of new workplaces, and thereby development of sources of population income is a determinant of the development of rural areas. Nowadays, multifunctional character of rural areas is the main postulate in spatial development plans, strategies of development as well as studies and growth forecasts concerning rural areas. Tourism, services, retail trade and housing industry have mainly been developing among various non-agricultural economic functions in rural areas of Poland. Nowadays, many rural households need additional sources of income in all parts of Poland. In contemporary times, the growth of 
diversity through development of functional structure is one of the key trends of development of rural areas Therefore, more and more attention is focused on the idea of development of nonagricultural economic functions.

The largest concentration of non-agricultural entities is observed in suburban zones and in the areas that are attractive with respect to tourism (Heffner, Twardzik 2015b, Maryáš et al. 2014, Ptaček, Szczyrba 2007). Their number per 10 thousand people at working age is over 1000 . Among them, the entities of service sector (predominantly retail trade) and manufacturing constitute the most numerous group. At the same time, services are the most rapidly developing economic activity in rural areas. Communes of suburban zones where mainly retail trade, construction, transport and wholesale entities are located are characterised by the largest concentration of services. Dynamics of changes in rural areas can be observed in frequent occurrence of discount chains in recent years (Dries, Reardon, Swinnen 2004). Investors of discount, supermarket and integrated stores recognise the possibilities of development not only in large cities and in rural areas.

Appearing in small towns and rural areas, discount and supermarket chains are in competition with local shops and local producers (i.e. Rochmińska 2016, Heffner 2013, Gazdecki 2010). The aim of the article is to show the scale of new retail investment in small towns and rural areas in Poland. Many studies highlight that it is a significant research and practical problem (Amcoff et al. 2011, van Leeuwen, Rietveld, 2011, Lukić, Jakovčić 2004, Powe, Shaw 2004, Sić 2007).

Research devoted to this field is important from the point of view of choosing the location of new investments related to discount and supermarket chains and of the strategy for the development of small towns and rural areas. Classical theories regarding the location of retail trade and services do not take into account the specificity of modern retail trade formats and conditions of their functioning in space (Guy 1998; Ozuduru, Varol, Ercoskun 2014; Czapiewski, Bański, Górczyńska 2016).

The paper was focused on the verification of the following research hypotheses:

- The development of retail chains in small towns and rural areas in Poland eliminates the activities of traditional forms of retail trade.

- Traditional stores in rural areas undertake integration activities in order to gain a competitive advantage.

- Market competition in rural areas takes place mainly between retail chains and integrated stores.

Identification of consequences of the operation of modern retail formats in chosen rural areas and in small towns can impact the verification of the policy adopted by local authorities in relation to spatial planning and forming the functional structure of the space (Brunetta, Caldarice 2016). It will result in more conscious (rational) decisions in terms of localising new discounts, which will reduce the number of local conflicts related to the location of such facilities.

\section{Conditions of retail trade development in Poland}

Retail trade in Poland belongs to economy sectors in which the processes of market changes were started the earliest. Discount stores that apply the strategy of low prices in the process of market conquering are currently one of the most dynamically developing selling formats. These shopping facilities are located in many Polish cities, including small towns and rural areas. Like in many Western countries, as well as in the Czech Republic and Slovakia, modern retail trade is expanding beyond urban areas (Spilková, Šefrna 2010).

Retailing in Poland is subject to constant structural, quantitative and qualitative changes. New large-selling area retail trade formats are emerging, and the number of shops is regularly decreasing. This mainly concerns tiny, small-scale grocery stores (25\% over the last five years), and shops with radio, television and computer equipment. They are replaced by discount stores that apply the strategy of low prices, multifunctional shopping centres and retail parks. Small towns and rural areas, which have been offering traditional retail trade formats so far, have become an attractive place for retail trade investors and location of their businesses (Rudawska, 
Bilińska-Reformat 2018, Paddison, Calderwood 2007). In general, these types of retail facilities increase the residential attractiveness of smaller centers and their rural surroundings (i.e. Fertner 2015). As a result of their expansion, discount stores and supermarkets of the largest retail operators in Europe are appearing in rural areas and in small towns (Tesco, Carrefour, Biedronka, Lidl, Netto). Residents are eager to take advantage of their offer and local entrepreneurs are struggling with growing competition. Spatial development of these areas is also changing because commercial chains have specific location, accessibility and technical requirements (e.g. the type of building, the size of plot).

For several years, retail trade has been moving from small local stores to discount chains that already account for nearly half of the total commercial space in Poland. Although there is still space for new investors, the market is slowly reaching the level of saturation with large-selling area stores, and experts forecast that its development will now be mainly related to consolidation and acquisition (Twardzik, Bilińska-Reformat 2016, Karasiewicz, Nowak 2010). At the same time, e-shops are rapidly growing. They are becoming serious competitors for traditional retail trade in an increasing number of sectors. However, the most significant changes do not concern the number of retail outlets, but broadly approached culture of retail trade. Because of greater choice, this is the consumer who is the party determining the terms of cooperation, that are based not only on the price criterion, but also on many other determinants affecting the comfort and quality of service. In the presence of growing competition, it seems necessary to understand this mechanism and follow the needs of contemporary customers to maintain and develop business. Both in Poland and in other European countries, retailing has multidimensional importance for economy and is one of its key sectors. According to a report prepared by DNB Bank Polska and Deloitte $^{3}$, retail trade companies generate 17 percent of gross value added, and the sectors indirectly associated with retail trade produce additional 12 percent. Retail trade also accounts for nearly 2 million workplaces, and another 1.6 million places of work in related sectors, which in total represents 26 percent of the working population. Although large retail chains entered Poland and new large-selling area stores are being opened, the value of retail trade market has been showing slight but constant decrease for several years. For the last 10 years, the overall number of stores has decreased by 25 percent and it is expected that in 2018, the total number of stores will have dropped to around 85,000. This includes decline in traditional retail trade stores by about 3 percent per year (source: report by Roland Berger Strategy Consultants). The causes of this phenomenon are primarily seen in the declining number of consumers, consolidations and takeovers of already existing outlets, as well as the development of new forms of retail trade (see: Adamowicz, Zaręba 2015). Large commercial chains and discount chains that have been developing at the rate of several \% in market value per year are still predominant. In 2013 in Poland, 432 discount stores were created, in the following years: $2014-275,2015-135,2016$ - 96 discount stores). Despite the greatest number of openings in all retail trade channels, a decline in the dynamics of development of discount chains has been observed. It seems that retail market is approaching the level of saturation with the discount forms and it is very likely in the near future there will be fewer and fewer new discount stores in the traditional appearance and form. In terms of the net turnover, Biedronka chain remains the leader. At the end of 2015, it had 2667 outlets. Also with respect to the total sales area, Biedronka remains the largest chain. In total, it has the space of over 1.7 million $\mathrm{m}^{2}$. Among Polish chains, ABC chain has the largest total sales area of 536 thousand $\mathrm{m}^{2}$, and among retail chains with Polish capital, Lewiatan can boast the highest level of revenue (including all regions).

Experts also noticed that the market is slowly becoming saturated by these store formats. Its future is seen among others, in the development of retail trade in smaller towns, especially in rural areas surrounding large and medium-sized towns, which currently are inhabited by around $24 \%$ of the population of Poland. Rapid development of online stores is also an important determinant affecting the situation on retail trade market in Poland. Because nowadays consumers have more options to choose from, they become the party that determine the terms of cooperation, and change the market according to their expectations. In the period of access to a large number of complementary products and services, the role of price as the main criterion of choice decreases,

${ }^{3}$ DNB Bank Polska Deloitte (2014). Kierunki 2014 - kluczowe czynniki determinujące handel w Polsce. Report (Trends 2014 - key determinants of retail trade in Poland). 
whereas the role of sales-related factors such as the level of service, broad assortment and convenience of transaction execution reflected in the access to various forms of payment among others is increasing (Schiffling, Karamperidis, Nelson 2015). Also, a Polish buyer who is a little loyal towards the store brand, constantly looks for bargain prices and at the same time appreciates high quality products, convenience, short shopping time and location in the neighbourhood, pose a challenge to retail chains. Discount chains, which are the main shopping place for urban and rural population in Poland, are currently conducting very similar marketing activities, which make them more and more alike in terms of price level, product range, promotional materials and store environment. To attract customers, discount stores are changing, while tailoring the offer to the needs of consumers. First of all, they are working on changing their perception - in the past the dynamic growth of discount stores was the result of positioning them as the cheapest shops, for the poorest consumers. At present, discount stores undertake several activities to be perceived as those "for everyone". Increasing the scope of assortment, particularly by adding popular brand products, and thus reducing the share of owned brands in the assortment is an example of such actions. Furthermore, discount stores are building shops in central locations so that it is more convenient for customers to do complex shopping there. Consumers pay increasingly more attention to the quality of the purchased products, while showing a high sensitivity to prices; the economic crisis of 2008-2010 has made price an important determinant when doing shopping. Consequently, the discounts that previously were mainly promoted by the lowest price, are now focusing on the quality of their products, developing the assortment of fresh products, and entering the organic food segment and the so-called world cuisine products, i.e. Greek or American week in Lidl, or Spanish cuisine in Biedronka. Suppliers of products sold under owned brand of discount chains are strictly tested with respect to their quality. Among manufacturers of food products, there is a conviction that supplying products to Biedronka is determined by having a prestigious quality certificate. Changes in discount chains can be considered the trend of "premisation" of discount stores that has been observed for some time on Polish market. It is related to weakening of the image typical of discount stores (based on low price and narrow assortment) and making them similar to supermarket pattern (i.e. Bilková et al. 2018). Consequently, consumers depart from doing big shopping once a week in a hypermarket if they can satisfy the same need faster and more conveniently in a nearby discount, usually offering the lowest prices and fresh products of high quality, at least in the opinion of the majority of customers from rural and small town areas. To survive the price battle, the chains start to form alliances within shopping groups and seek new possibilities for expansion particularly in rural areas.

\section{The process of rural development in Poland}

Non-agricultural business activity conducted in rural areas is considered indispensable for their economic development. It is essential for farms particularly operating in the areas of less favourable conditions for agricultural production (Spilková, Perlín 2013). The growth of economic diversity is currently the most important trend of development of rural areas.

Nowadays, multifunctional character of rural areas is the main postulate in spatial development plans, strategies of development as well as studies and growth forecasts concerning rural areas. Tourism, services, retail trade and housing industry have mainly been developing among various non-agricultural economic functions in rural areas of Poland. Many rural households need additional sources of wealth in all parts of Poland. In contemporary times, the growth of diversity through development of functional structure is one of the key trends of development of rural areas Therefore, more and more attention is focussed on the idea of development of non-agricultural economic functions. Among over 3 million business entities operating in Poland, around 700 thousand were located in rural areas. According to Bański (2017), considering the fact that rural areas constitute over $90 \%$ of the area of the country and are inhabited by almost $40 \%$ of total population, it ought to be stated that the number of business entities in rural areas is scarce. At the same time, the largest numbers of entities were observed in rural areas in large city hinterlands, whereas the least were in peripheral areas (compare Maryás et al. 2014). Concentration of non-agricultural business activity in the areas located in the neighbourhood of cities is a result of better developed technical infrastructure, and better structure of education of 
the population. Additionally, entrepreneurs increasingly more often locate their business entities in rural areas mainly because of the prices of land that are significantly lower than in cities (Knox, Meyer 2011). Non-agricultural business activity in rural areas in Poland has been developing at an unequal pace. Business activities of non-agricultural character show the largest density and share in western regions (Zachodniopomorskie and Pomorskie, Dolnośląskie, and Lubuskie), as well as in the Central and Southern parts of the country (Mazowieckie and Śląskie voivodships). On the other hand, the smallest saturation with such entities was reported in eastern voivodships (Podkarpackie, Lubelskie, Podlaskie). The largest concentration of non-agricultural entities is observed in suburban zones and in the areas, that are attractive with respect to tourism. Their number per 10 thousand people at working age is over 1000. Among them, the entities of service sector (mainly retail trade, particularly discount and integrated chains) and manufacturing constitute the most numerous group. At the same time, services are the most rapidly developing economic activity in rural areas. Communes of suburban zones where mainly retail trade, construction, transport and wholesale entities are located can be characterized as the largest concentration of services. Explicitly emerging trend of migration of city population to rural areas is a new phenomenon in rural areas in Poland. The process of suburbanisation brings growth of importance of housing and retail trade functions of rural areas (compare Ptaček, Szczyrba, 2007). The largest concentration and dynamics of growth of the function occur in suburban zones of large urban and industrial agglomerations (Gazdecki 2010). This creates conditions conducive to the development of rural areas, and favours improvement of technological and social infrastructure. Low incomes of the population in rural areas are the major reason for low demand on offered services and products. This is the main cause for decline in the dynamics of establishment of new business entities, particularly those working in provision of services to local market. Lack of capital also hampers development of activity in rural areas. The emergence of new economic functions in rural areas would definitely improve the situation of agriculture, starting from making the surplus in labour force productive, to modernisation of production processes and occurrence of broader scope of services provided to agriculture. Unfortunately, multi-functional development of rural areas is often only a slogan that is not translated into reality. Revolutionary changes in the sphere of functionality of these areas can hardly be expected because the state economy, or particularly rural areas and agriculture are not prepared for rapid acceleration. Dynamics of changes in rural areas can be observed in frequent occurrence of discount chains in recent years (i.e. Kulke 1997; Heffner, Twardzik 2015a). Investors of discount and integrated stores recognise the possibilities of development not only in rural areas in the surroundings of large cities, but also far from the city.

\section{Modern retail trade formats in rural development in Poland}

Structural changes of retail trade chains that have been observed so far in big cities and agglomerations started to occur in small towns and rural areas because of new investments, i.e. discount stores and supermarkets. Commercial chains started to search for new areas for location of their investments in smaller canters in which there is no competition yet, but there is a demand on commercial facilities of this type.

Despite a growing number of modern retail trade formats and the fact that they gain importance in the size and value of shopping in rural areas, traditional small-format retail trade, often referred to as local market, is also really important. Obviously, it will never constitute such a large potential for retailers like business in large cities (compare Maruyama, Wu 2014). However, considering socio-demographic structure of Polish society and the fact that almost $38 \%$ Polish citizens and $32 \%$ of households reside and live in rural areas, local retail trade is extremely important. Rural areas account for the largest part of purchased grocery assortment - over $30 \%$. New trends observed in rural areas mainly include development of franchise and discount stores, adjustment of offer to local customer and aiming at high satisfaction, as well as providing services to local customer, i.e. the tailored offer. Discount stores emerge more and more frequently in rural areas, particularly in suburban or tourist communes. After 2010 exceptional growth in the number of discount stores and shopping centres has been observed, whereas the speed of growth of super and hypermarket stores has been declining. New retail forms and facilities became more visible in small towns and new trading posts were predominantly located in the zones of influence of 
bigger cities. They affect many changes of spatial, social and economic character. Small towns and rural areas surrounding them more and more frequently started to compete for further commercial investments while noticing lots of benefits resulting from them.

The structure of retail trade chains in rural areas in Poland is subject to constant quantitative and qualitative changes. Essential changes of quantitative character include decrease in the number of commercial outlets, particularly the smallest ones up to $50 \mathrm{~m}^{2}$ of usable area, providing employment up to nine people and usually managed by domestic family enterprises, and increase in the number of stores of the area over $300 \mathrm{~m}^{2}$. Qualitative changes mainly concern the process of progressing spatial, organisational and technical as well as capital concentration, and the process of integration in retail trade. Discount stores are one of the fastest developing forms of contemporary retail trade. In recent years, increase in the number of integrated chains particularly those trading in grocery products (i.e. Lewiatan, Żabka, Groszek, Małpka and Społem) has been observed. They offer both standardised conditions of service as well as commercial and price offer for customer.

Retail trade and services are becoming the most dynamically developing sector of nonagricultural activity in rural areas. The largest concentration of services is observed in suburban areas where mainly transport, repair and construction services, as well as commercial chains and wholesale companies are located. New economic reality is characterized by developing retail trade in rural areas. State-owned and cooperative stores have been closed down and they were replaced mostly by private stores. There are increasing number of commercial outlets of various formats, including supermarket chains, discount stores and integrated chains located in suburban areas. Apart from retail trade function, tourism and recreation have been developing in rural areas. Ecological farming approached as a new dimension in agricultural production became more popular also. A lot of investments are initiated by projects implemented from European Union subsidies. Rural areas in Poland have been changing with respect to their structure, functions and landscape for a decade.

Therefore, emergence of new commercial facilities in small towns and rural areas has a positive impact on their functional and spatial development. Nevertheless, it forms a competitive threat to traditional forms of sale in small shops, in marketplaces and other forms of small retail trade. Small towns and rural areas in Poland in majority of cases are still searching for the path of development appropriate for them and in accordance with their capabilities.

\section{Modern retail trade formats in rural areas in Poland (2012-2015) - results of research}

In recent years, discount and integrated chains have been expanding to the most of the small towns, and directly to well-located and concentrated villages with sufficient population potential in rural areas (direct research 2016 ${ }^{4}$ ), (Figure 1, table 1).

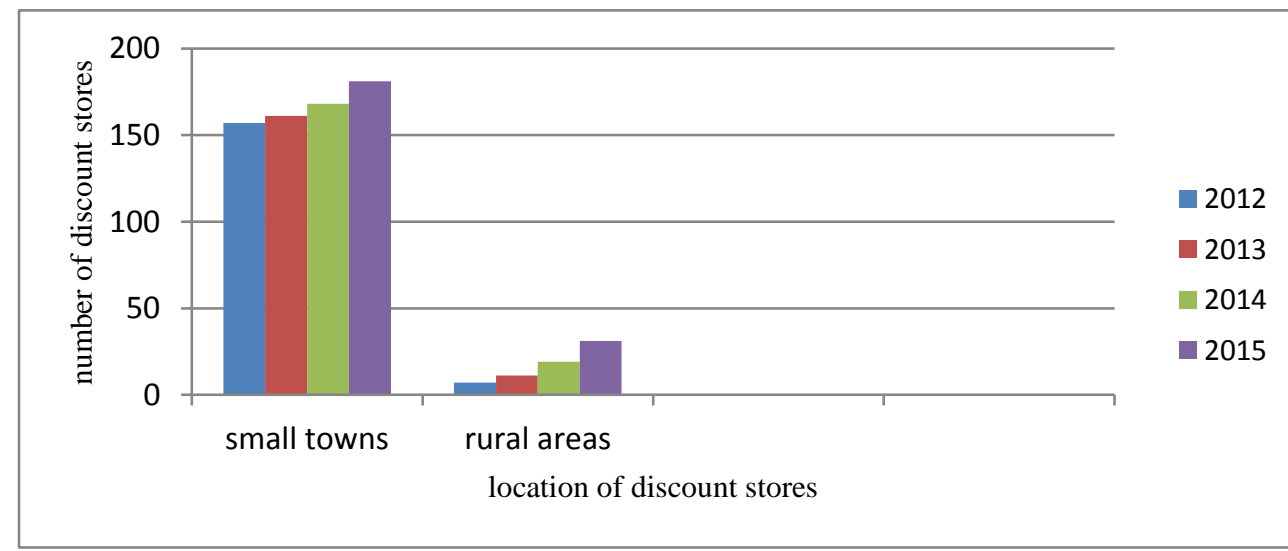

Fig 1. Number of discount stores in small towns and rural areas in Poland (2012-2015). Source: Own study

\footnotetext{
${ }^{4}$ Research conducted in 2016 in discount chains and integrated chains operating in Poland. Statistical data of trade chain reporting and reporting data were used.
} 
Tab 1. Number of integrated retail chains in small towns and rural areas in Poland (2012-2015). Source: Own study ${ }^{5}$

\begin{tabular}{|c|c|c|}
\hline \multirow{2}{*}{ Year } & \multicolumn{2}{|c|}{ Number of Integrated retail chains } \\
\cline { 2 - 3 } & Small towns & Rural areas \\
\hline 2012 & 1023 & 188 \\
\hline 2013 & 1586 & 201 \\
\hline 2014 & 1607 & 388 \\
\hline 2015 & 1790 & 416 \\
\hline
\end{tabular}

The steadily increasing number of discount stores and integrated chains in small towns, especially with central location in more densely populated rural zones, analogically grows in rural areas however, in a much smaller scale (i.e. Vaishar, Zapletalová 2008). The number of discount stores located directly in rural areas in Poland was only 19 stores (2015). The leader among the discounters invested in rural areas in Poland is absolutely Biedronka, the Portuguese operator. It can be considered that the company has a monopoly on investments in rural areas (Fig. 2). The most attractive for retail investors are the villages with features of central places (including administration and public services as well as the population potential of rural surroundings at the level of 6-10 thousand people (compare conclusions in the paper Drobek, Heffner 1994).

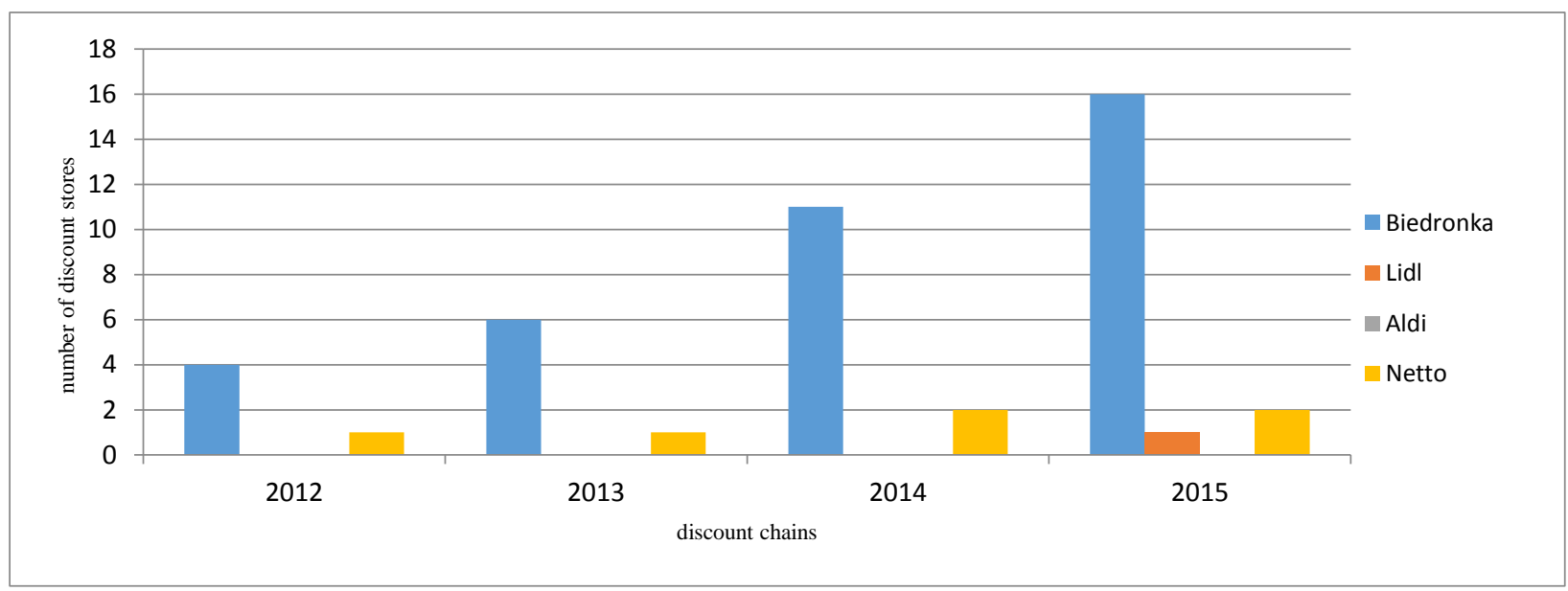

Fig 2. Number of discount stores in rural areas in Poland (2012-2015). Source: Own study

The leaders of integrated retail chains in rural areas of Poland are Żabka, Groszek and Lewiatan.

Economists note worrying phenomenon in small towns, where the construction of the discount store is combined with an increasing fall in number of local retailers falls (Maleszyk, 2003, Heffner, Twardzik 2015b). While in the case of a big urban center, such process affects the shape of the settlements so much in a small town that it entails consequences for the whole urban unit.

The development process of discount stores in Poland is very dynamic. Discount stores located in small towns and rural areas may change the functional structure of the area. Over time, the number of small retail trade establishments may be reduced due to the loss of a significant part of the customers which confirms the hypothesis that modern retail chain eliminates the activities of traditional forms of retail trade in small towns and rural areas in Poland. Among positive boosts to the development related to the construction of discount stores, the respondents enumerated the creation of new jobs in both retail and service sectors.

\footnotetext{
${ }^{5}$ On the basis of address locations discount chains in Poland in 2012-2015.
} 
Tab 2. The largest integrated retail chains in rural areas in Poland (2012-2015). Source: Own study

\begin{tabular}{|c|c|c|c|}
\hline \multirow{2}{*}{ Year } & \multicolumn{3}{|c|}{ Number of integrated retail chains } \\
\cline { 2 - 4 } & Żabka & Groszek & Lewiatan \\
\hline 2012 & 52 & 34 & 32 \\
\hline 2013 & 68 & 36 & 44 \\
\hline 2014 & 86 & 41 & 67 \\
\hline 2015 & 96 & 45 & 82 \\
\hline
\end{tabular}

In the areas of small towns and rural communes, progressive and diversified transformations of the structure of retail trade can be observed, as a result of changes in the consumer behavior. The intensity of modifications depends on the size of a given commune and the number of discount stores in the retail trade chain. In rural communes, functional and spatial transformations related to the retail sector take place at a slower pace (much more considerable changes concern residential areas), while in small and medium-sized towns they result mainly from the expansion of grocery supermarket chains. Market competition in rural areas takes place mainly between retail chains and integrated stores. Traditional stores do not have the economic potential to compete with modern retail chains.

Negative changes, consisting mainly in the liquidation of small shops, are considered to be a natural consequence of market gambling. Conducted analysis allows the formulation of several conclusions concerning the importance of modern retail trade for functional and spatial structure of rural communes. Gradual and diversified transformations in the retail trade structure caused by changes in consumer behaviours occur, and intensity of changes depends on the commune size and its proximity of metropolitan area (i.e. Heffner 2013). In rural communes, functional and spatial transformations concerning retail trade sector progress the most slowly, whereas in small towns they mainly result from expansion of discount or integrated chains. Modern retail trade formats are profitable for the commune (increased tax revenues and local fees and new workplaces), and for customers / residents (greater comfort of shopping, wide choice of products and lower prices). Closing down small shops is perceived as a natural consequence of market game, and retail trade and service sector is not the major determinant of development from the point of view of local authorities. In their efforts to attract external investors, local government leaders are mainly focused on manufacturing companies and developers (housing developers). Impact of commercial outlets on small towns and rural areas is a dynamic process in time and form, thus it needs further, regular scientific research.

\section{Academic references}

[1] Adamowicz, M. \& Zaręba, M. (2015). Nowe formy handlu detalicznego w dużych i małych miastach Polski. Economic and Regional Studies, 8(4), 5-27.

[2] Amcoff, J., Moller, P. \& Westholm, E. (2011). The (un)importance of the Closure of Village Shops to Rural Migration Patterns. The International Review of Retail, Distribution and Consumer Research, 21(2), 129-143. DOI: 10.1080/09593969.2011.562678.

[3] Bański, J. (2017). The future of rural Poland: the main trends and possible scenarios, Eastern European Countryside 23, 71-102. DOI: 10.1515/eec-2017-0004.

[4] Bilková, K., Križan, F., Horňák, M., Barlík, P. \& Zubriczky, G. (2018). Food and non-food retail change in a post-communist country: A case study of the Gemer region in Slovakia. Bulletin of Geography. Socio-economic Series 39, 7-20. DOI: 10.1515/16164.

[5] Brunetta, G. \& Caldarice, O. (2016). Retail Planning for Regional Development: The Design of Resilient Scenarios in Trentino (Italy). Journal of Civil Engineering and Architecture 10, 1173-1182. DOI: 10.17265/1934-7359/2016.10.009. 
[6] Czapiewski, K., Bański, J. \& Górczyńska, M., (2016). The impact of location on the role of small towns in regional development: Mazovia, Poland. European Countryside 8(4), 413426. DOI: 10.1515/euco-2016-0028.

[7] Dries, L., Reardon, T. \& Swinnen, J. (2004). The Rapid Rise of Supermarkets in Central and Eastern Europe: Implications for the Agrifood Sector and Rural Development. Development Policy Review 22(5), 525-556. DOI: 10.1111/j.1467-7679.2004.00264.x.

[8] Drobek, W. \& Heffner, K. (1994). Koncepcja wsi kluczowych a procesy osadnicze na obszarach wiejskich, Przegląd Geograficzny 65(1-2), 19-31.

[9] Fertner, C., Groth, N. B., Herslund, L. \& Carstensen, T. A. (2015). Small towns resisting urban decay through residential attractiveness. Findings from Denmark. Geografisk Tidsskrift 115(2), 119-132. DOI: 10.1080/00167223.2015.1060863.

[10] Gazdecki, M. (2010). The concentration of retail in Poland. Journal of Agribusiness and Rural Development 16(2), 41-48.

[11] Guy, C. (1998). Classifications of retail stores and shopping centres: some methodological issues. GeoJournal, 45(4), 255-264. DOI: 10.1023/A:1006960414161.

[12] Heffner, K. (2013). The outer metropolitan zone, In Heffner, K., Twardzik, M., eds., The Impact of Shopping Malls on the Outer Metropolitan Zones (The Example of the Silesian Voivodeship) (pp. 12-19). Warsaw: Polish Academy of Sciences. Committee for Spatial Economy and Regional Planning.

[13] Heffner, K. \& Twardzik, M. (2015a). Leaching functions from the outer metropolitan zones (trade, services) - increasing peripherality of small towns and rural areas. Journal of Economics and Management, 19(1), 194-209.

[14] Heffner, K. \& Twardzik, M. (2015b). The Impact of Shopping Centers in Rural Areas and Small Towns in the Outer Metropolitan Zone (The Example of the Silesian Voivodeship), European Countryside, 7(2), 87-100. DOI: 10.1515/euco-2015-0006.

[15] Karasiewicz, G. \& Nowak, J. (2010). Looking back at the 20 years of retailing change in Poland. The International Review of Retail Distribution and Consumer Research 20(1), 103 117. DOI: $10.1080 / 09593960903509627$.

[16] Knox, P. L. \& Meyer, H. (2011). Europe's Internal Periphery. Small Towns in the Context of Reflexive Polycentrity. In Lorentzen, A., van Heur, B., eds., Cultural Political Economy of Small Cities (pp. 156-172). London: Routledge.

[17] Kulke, E. (1997). Effects of the economic transformation process on the structure and locations of retailing in East Germany. Journal of Retailing and Consumer Services 4(1), 4955. DOI: 10.1016/0969-6989(95)00084-4.

[18] van Leeuwen, E. S. \& Rietveld, P. (2011). Spatial Consumer Behaviour in Small and Mediumsized Towns. Regional Studies 45(8), 1107-1119. DOI: 10.1080/00343401003713407.

[19] Lukić, A. \& Jakovčić, M. (2004). Location and Functions of Hypermarkets and Shopping Centres in Zagreb. Dela 22, 39-54.

[20] Maleszyk, E.. (2000). Ośrodki handlowe w Polsce-uwarunkowania, kierunki rozwoju. In: Rynek i konsumpcja. Warszawa: Institute for Market, Consumption and Business Cycle Research.

[21] Maleszyk, E. (2003). Handel dyskontowy w Polsce. Warszawa: Instytut Rynku Wewnętrznego i Konsumpcji.

[22] Maruyama, M. \& Wu, L. (2014). Quantifying barriers impeding the diffusion of supermarkets in China: The role of shopping habits, Journal of Retailing and Consumer Services 21(3), 383-393. DOI: 10.1016/j.jretconser.2013.11.002. 
[23] Maryáš, J., Kunc, J., Tonev, P. \& Szczyrba, Z. (2014). Shopping and Services Related Travel in the Hinterland of Brno: Changes from the Socialist Period to the Present, Moravian Geographical Reports, 22(3), 18-28. DOI: 10.2478/mgr-2014-0015.

[24] Ozuduru, B. H., Varol, C. \& Ercoskun, O. Y. (2014). Do shopping centers abate the resilience of shopping streets? The co-existence of both shopping venues in Ankara, Turkey. Cities 36, 145-157. DOI: 10.1016/j.cities.2012.10.003.

[25] Paddison, A. \& Calderwood, E. (2007). Rural retailing: a sector in decline? International Journal of Retail \& Distribution Management 35(2), 136-155. DOI: $10.1108 / 09590550710728093$.

[26] Powe, N. A. \& Shaw, T. (2004). Exploring the Current and Future Role of Market Towns in Servicing Their Hinterlands: a Case Study of Alnwick in the North East of England. Journal of Rural Studies 20(4), 405-418. DOI: 10.1016/j.jrurstud.2004.07.003.

[27] Ptaček, P. \& Szczyrba, Z. (2007). Current suburbanisation trends in the Czech Republic and spatial transformation of retail. Revija za geografijo 2(1), 55-65.

[28] Rochmińska, A. (2016). Shopping Centres as the Subject of Polish Geographical Research. Geographia Polonica 89(4), 521-535. DOI: 10.7163/GPol.0072.

[29] Rudawska, E. D. \& Bilinska-Reformat, K. (2018). The development of food retail formats evidence from Poland. British Food Journal 120(2), 309-324. DOI: 10.1108/BFJ-02-20170064.

[30] Schiffling, S., Karamperidis, S. \& Nelson, J. D. (2015). Local Shops vs. Online Retailers: Competition or Synergy? Scottish Geographical Journal, 131(3-4), 220-227. DOI: $10.1080 / 14702541.2014 .978805$.

[31] Sić, M. (2007). Spatial and Functional Changes in Recent Urban Development of Zagreb. Dela 27, 5-15.

[32] Spilková, J. \& Perlín, R. (2013). Farmers' markets in Czechia: Risks and possibilities, Journal of Rural Studies 32, 220-229. DOI: 10.1007/s10460-012-9395-5.

[33] Spilková, J. \& Šefrna, L. (2010). Uncoordinated new retail development and its impact on land use and soils: A pilot study on the urban fringe of Prague, Czech Republic, Landscape and Urban Planning 94(2), 141-148. DOI: 10.1016/j.landurbplan.2009.09.001.

[34] Twardzik, M. (2013). Development of shopping malls in Poland. In Heffner, K., Twardzik, M., eds., The impact of shopping malls on the outer metropolitan zones (the example of the Silesian Voivodship) (pp. 42-63). Warszawa: KPZK PAN.

[35] Twardzik, M. \& Bilińska-Reformat, K. (2016). Discount chains in the small towns and rural areas in Poland. Studia Regionalia 46, 59-72.

[36] Vaishar, A. \& Zapletalová, J. (2009). Small towns as centres of rural micro-regions, European Countryside 1(2), 70-81. DOI: 10.2478/v10091-009-0006-4.

Other sources

[37] Stych, M. (2011). planetretail.net/Global Retail Trends and Forecasts (07.08.2016). http://retailanalysis.igd.com/2013 (07.08.2016).

[38] Taccet, K. (2014.) planetretail.net/ European Grocery Retailing, Change is the only constant (09.08.2016).

[39] https://www2.deloitte.com/pl/pl/pages/press-releases/.../handel-w-polsce-2014.html (22.06.2014)

[40] www.icsc.org (21.08.2016); https://www.rolandberger.com (16.07.2016). 